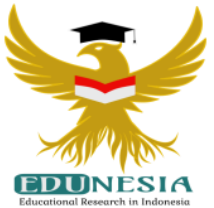

\title{
Development of Student Worksheet Based on Problem to Improve Student's Mathematics Communication Skills
}

\author{
Fardila Hayati ${ }^{1}$; Arief Aulia Rahman'2; Cut Eva Nasryah ${ }^{3}$ \\ 1,2Department of Mathematic Education, STKIP Bina Bangsa Meulaboh, Indonesia \\ ${ }^{3}$ Department of Primary Education, STKIP Bina Bangsa Meulaboh, Indonesia \\ ${ }^{1}$ Corresponding Email: fardilahayati19@gmail.com, Phone Number: $0822 \times x \times x \times x \times x$
}

\begin{abstract}
Article History:
Received: Jan 08, 2021

Revised: May 05, 2021

Accepted: May 22, 2021

Online First: Jun 02, 2021
\end{abstract}

Keywords:

Dick \& Carrey,

Mathematical

Communication, Problem

Based Learning, Research \& Development, Student worksheets.

Kata Kunci:

Dick \& Carrey, Komunikasi Matematis, Lembar kerja siswa, Pembelajaran

Berbasis Masalah, Research \& Development.

\footnotetext{
How to cite:

Hayati, F., Rahman, A.A., \& Nasryah, C.E. (2021). Development of Student Worksheet Based on Problem to Improve Student's Mathematics Communication Skills. Edunesia: Jurnal Ilmiah Pendidikan, 2 (2): 557-568.
}

This is an open access article under the $C C-B Y-N C-N D$ license

\begin{abstract}
This study aims to describe: (1) the validity of student worksheets based on problem; (2) increasing the mathematical communication skills of high school students by using student worksheets based on problem; (3) student responses to the development of student worksheets based on problem. This research is research and development. This research was conducted using Dick and Carrey model. The population in this study were all students of class $X$ Darul Aitami private high school. Sampling used simple random sampling and the classes used as samples for the trial were class X-1 and class X-2. From the results of trial 1 and trial 2 it can be obtained: (1) student worksheets are included in the valid category, reviewed from several aspects, namely: format, language, material, and content. (2) the improvement of students 'mathematical communication skills by using student worksheets based on problem increased by $6.9 \%$, in the first trial results the students' average score was $73.4 \%$ and after conducting the second trial it increased by $80.3 \%$. (3) student responses to the components of student worksheets and learning activities using student worksheets are positive. Furthermore, it is suggested that teachers can use student worksheets based on problem as an alternative to learning, with the guidance or questions provided that are affordable to students, so that students understand the problems they are given more easily.
\end{abstract}

\begin{abstract}
Abstrak: Penelitian ini bertujuan untuk mendeskripsikan: (1) kevalidan lembar kerja siswa berbasis masalah; (2) peningkatan kemampuan komunikasi matematis siswa sekolah menengah atas dengan menggunakan lembar kerja siswa berbasis masalah; (3) respon siswa terhadap pengembangan lembar kerja siswa berbasis masalah. Penelitian ini merupakan penelitian pengembangan. Penelitian ini dilakukan menggunakan model Dick and Carrey. Populasi dalam penelitian ini adalah seluruh siswa kelas X SMA Swasta Darul Aitami. Pengambilan sampel menggunakan simple random sampling dan kelas yang dijadikan sebagai sampel untuk uji coba adalah kelas X-1 dan kelas X-2. Dari hasil uji coba 1 dan uji coba 2 dapat diperoleh: (1) lembar kerja siswa masuk dalam kategori valid, di tinjau dari beberapa aspek yaitu: format, bahasa, materi, dan isi. (2) peningkatan kemampuan komunikasi matematis siswa dengan menggunakan lembar kerja siswa berbasis masalah meningkat sebesar $6,9 \%$, pada hasil uji coba I nilai rata-rata siswa 73,4\% dan setelah melakukan uji coba II meningkat sebesar $80,3 \%$. (3) respon siswa terhadap komponenkomponen lembar kerja siswa dan kegiatan pembelajaran dengan menggunakan lembar kerja siswa adalah positif. Selanjutnya, disarankan agar guru dapat menggunakan lembar kerja siswa berbasis masalah sebagai alternatif pembelajaran, dengan bimbingan atau pertanyaan-pertanyaan yang diberikan dapat terjangkau oleh siswa, sehingga siswa lebih mudah memahami masalah-masalah yang diberikan.
\end{abstract}




\section{A. Introduction}

Good education is that not only prepares students for a particular profession or position, but also for solving problems faced in everyday life. The goals of each educational unit must refer to the achievement of national education goals. National education aims to develop the potential of students to become human beings who believe and have faith in God Almighty, have noble character, are creative and independent (Zaini, 2011).

Often times students even find fear in doing math problems. The indication can be seen from the unsatisfactory student learning outcomes. According to Marpaung (Betharia, 2016) the quality of mathematics education in Indonesia on a national scale is still unsatisfactory. This can be seen in the low quality of students' mathematical skills which is reflected in the results of the International Survey The Trend International Mathematics and Science Study (TIMSS) and the Program for International Student Assessment (PISA) in 2011, Indonesia only ranks 38 with a score of 386 out of 42 country.

The need for mathematical communication of students in studying mathematics. This is because mathematics is a language and a tool, mathematics uses clear definitions and special symbols that can be used in life, it also makes it easier for students to understand maths lessons in order to make it easier for students to solve math problems. Ansary (2012) states that there are at least two important reasons why communication in mathematics needs to be cultivated among students. (1) mathematics as language, meaning that mathematics is not only a tool for thinking, a tool for finding patterns, solving problems or drawing conclusions, but mathematics is also a diverse tool for communicating various ideas in a clear, accurate, and precise manner. (2) mathematics learning as social activity, meaning as a social activity in mathematics learning, but also as a vehicle for interaction between students and also communication between teachers and students. Therefore, the existence of students' mathematical communication skills will accelerate students' mathematical understanding.

The results of preliminary observations made by researchers in the mathematics learning process that took place at the Darul Aitami Private High School, found that there was no character worksheet used by mathematics teachers in the mathematics learning process. The teacher only uses one textbook, while the students do not have the textbook. Students are only loaned textbooks during the lesson. In the learning process students must record the material delivered by the teacher.

The difficulty of students in solving problems because students' mathematical communication skills are still concerning, this can be seen from the questions given by researchers to class X students of Darul Aitami Private High School, on the material of the two-variable linear equation system. The following is the result of question completion by one of the Darul Aitami Private High School students:

$\begin{aligned} & \text { Students have not been able to } \\ & \text { apply the formulas that have } \\ & \text { been learned and feel confused } \\ & \text { about what formulas will be } \\ & \text { applied to solve the questions } \\ & \begin{array}{l}\text { so that students cannot answer } \\ \text { the questions correctly. }\end{array}\end{aligned}$
$\begin{aligned} & 3 x+4 y=3 \\ & 4 x-4 y=32\end{aligned}$
$\begin{aligned} & 7 x=35 \\ & 4 x-y=3\end{aligned}$

Figure 1. students' answers to mathematical communication skills questions. 
Aristia et al (2020) states that one of the determining factors for a good mathematics learning system is the teacher. Therefore, it is necessary to have teachers who are able to carry out the mathematics learning process properly. The main task of the teacher is to educate, teach, guide, direct, train, assess, and evaluate. A teacher to be able to complete his duties must have professional abilities.

There are many ways that educators can teach material that is memorable for students, from choosing teaching materials, learning models, teaching aids, learning media, and so on. Student worksheets are printed teaching materials in the form of paper sheets containing material, summaries, and instructions for implementing learning tasks that must be done by students, which refer to the basic competencies that must be achieved. According to Majid (2017) student worksheets are sheets containing tasks that must be done by students. Student worksheets should be arranged by providing questions that can make students more active and encourage students to develop their mathematical skills in improving students' mathematical communication. Darul Aitami Private High School, does not yet have a worksheet that guides students in communicating the material they are learning. Most teachers only provide practice questions in the book and have not fulfilled the student worksheets elements, so this can be one of the causes of low student learning outcomes. The low student learning outcomes, namely from the inaccurate selection of models, methods and learning media (Sulastri, 2017). The student worksheets at Darul Aitami Private High School, are as follows:

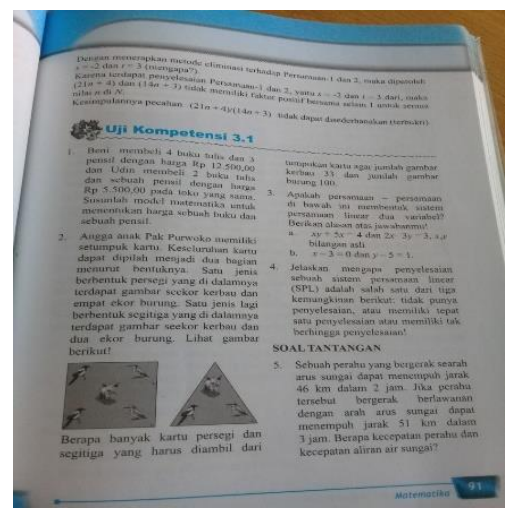

Figure 2. Student worksheets in schools

One work step that can lead students to communicate mathematics is by using problem-based learning strategies where the steps of problem-based learning strategies can lead students to be able to communicate the mathematics they are learning, because problem-based learning is a teaching method characterized by problems. real as a context for students to learn skills, solve problems, and gain knowledge, so that students are more focused in solving math problems. This is in line with the opinion of learning and teaching support network (Kurniawati et al, 2016), which states that one thing that can be improved from student activity in solving problems is students' mathematical communication skills.

The need for student worksheets that can improve students' mathematical communication skills. So it is very appropriate to conduct research and development of student worksheets on problem-based two-variable linear equation material to improve students' mathematical communication. 


\section{B. Method}

This research is a research and development, the product of this research and development is a student worksheet based on problem. The purpose of this development research is to describe: (1) the validity of Student Worksheets based on problem; (2) improving students' mathematical communication skills by using Student Worksheets based on problem; (3) student responses to Student Worksheets based on problem.

The population in this study were all class X students of Darul Aitami Private High School. Sampling in this study using simple random sampling. The school that is used as the sample of this research is class X-1 Darul Aitami Private High School, on the material of two-variable linear equation system. Trial I was conducted in class X-I of Darul Aitami Private High School and Trial II was conducted in class X-1I of Darul Aitami Private High School. The reasons and considerations in selecting the sample, namely the schools sampled have the same characteristics seen from the learning time, student characteristics, and the material being studied.

The development model used in this research is the Dick \& Carey model. Dick and Carey development model has 10 stages in the development and design process, namely: (1) identification of learning objectives, (2) learning analysis; (3) student analysis and context; (4) determining learning objectives; (5) developing assessment instruments; (6) developing learning strategies; (7) developing and selecting learning materials; (8) designing and conducting formative evaluations; (9) revision; (10) designing and conducting a summative evaluation.

Analysis of the validity of student worksheets, which is based on the results of this validation analysis, is based on the opinions of two experts in the field of mathematics education. based on the opinion of the mathematician, the average value for each aspect will be determined, so that the average value for the total aspects is obtained. Using the formula:

$$
\mathrm{x}=\frac{\sum x i}{n} \quad \text { (Sudjana, 2005) }
$$

Table 1. criteria for the level of validity of student worksheets

\begin{tabular}{cc}
\hline$V a$ or the total mean value & validity criteria \\
\hline $1 \leq V a<2$ & Invalid \\
$2 \leq V a<3$ & Enough \\
$3 \leq V a<4$ & Valid \\
$V a=4$ & Very Valid \\
\hline
\end{tabular}

Student worksheets are said to be valid if the mean value of the two validators reaches 3-4, then it can be said to be included in the valid or suitable category for use. The analysis of the improvement of students' mathematical communication was obtained from the posttest results of mathematical communication skills in trials I and II by comparing the average score obtained by students and the average score for each indicator of mathematical communication from the results of the posttest trials I and II can be analyzed using criteria following: 
Table 2. criteria for increasing students' mathematical communication skills

\begin{tabular}{cc}
\hline $\begin{array}{c}\text { Interpretation of test } \\
\text { validity }\end{array}$ & validity criteria \\
\hline $0,800-1,00$ & Very High \\
$0,600-0,800$ & High \\
$0,400-0,600$ & Not High enough \\
$0,200-0,400$ & High enough \\
$0,00-0,200$ & Very low \\
\hline
\end{tabular}

Students' mathematical communication is said to increase when the student's score reaches 80 . The data analysis of the student response questionnaire results was analyzed using quantitative descriptive by presenting the positive and negative responses of the students in filling out the student response questionnaire sheets calculated by the formula:

$$
\% \text { response to every aspect }=\frac{\text { the number of students responding }}{\text { total number of students }} \times 100 \%
$$

To determine the achievement of learning objectives from student responses, it is assessed from the number of students who give a positive response greater than or equal to $80 \%$ of the number of subjects studied for each trial.

Validator of validation data, student mathematical communication improvement data and student response questionnaire data are analyzed so that student worksheets are known in terms of validity, student mathematical communication and student responses to student worksheets.

\section{Result and Discussion}

\section{Identify learning objectives}

At this stage, the researcher conducted several analyzes which will be presented in the following table.

Table 3. data analysis results

\begin{tabular}{l|l}
\hline \multicolumn{1}{c}{ Analysis stage } & \multicolumn{1}{c}{ Analysis results } \\
\hline $\begin{array}{l}\text { Needs analysis } \\
\text { (material and } \\
\text { curriculum) }\end{array}$ & a. $\begin{array}{l}\text { The curriculum used by Darul Aitami Private High } \\
\text { School is the 2013 curriculum. }\end{array}$ \\
& $\begin{array}{l}\text { b. In mathematics, especially in the material of the two- } \\
\text { variable liner equation system at Darul Aitami } \\
\text { Private High School, it has not used student } \\
\text { worksheets. }\end{array}$ \\
$\begin{array}{l}\text { Needs analysis } \\
\text { (scoring system) }\end{array}$ & $\begin{array}{l}\text { Through observations made by researchers in class X } \\
\text { SMA Private Darul Aitami, information was obtained } \\
\text { that so far there has been no math worksheets, especially } \\
\text { in the material of two-variable linear equation systems. }\end{array}$ \\
\hline
\end{tabular}




\section{Instructional analysis stage}

At this stage, several instructional objectives are obtained regarding relevant skills and are needed by students to achieve competency or learning objectives. The skills that must be mastered by students especially in the realm of mathematical communication can be seen in the following table:

Table 4. mathematical communication skills

\begin{tabular}{clc}
\hline Stages & \multicolumn{1}{c}{ Indicator } & $\begin{array}{c}\text { Number of } \\
\text { test }\end{array}$ \\
\hline Write & $\begin{array}{l}\text { Students can explain the situation criteria from a given } \\
\text { picture / graphic in their own words in written form. }\end{array}$ & \\
Draw & Students can state a situation with pictures / graphics. & $1,2,3$ \\
$\begin{array}{c}\text { Mathematical } \\
\text { expressions }\end{array}$ & $\begin{array}{l}\text { Students can express a situation into a mathematical } \\
\text { model }\end{array}$ & \\
\hline
\end{tabular}

\section{Identifying the characteristics of students stage}

At this stage, the researcher analyzed the character of students at Darul Aitami Private High School, especially in the class that would be the test subjects in this study, namely class X MIA II. The results are as follows:

a. Students who are in class X MIA II Darul Aitami Private High School are students who need more guidance than $X$ MIA I.

b. The students of X MIA II SMA consist of 22 students.

c. The actual ability of students in this class is relatively low, they do not understand the lessons given by the teacher. They have difficulty in learning mathematics, especially in the material of two-variable linear equation systems, but there are some students who can catch the lesson by practicing questions using the discussion method.

\section{Stage of formulating specific learning goals}

From this stage, several formulations of specific learning objectives regarding students' mathematical communication skills must be mastered by students, including the following:

a. Students can communicate story problems into mathematical symbols on the material of two-variable linear equation systems.

b. Students can solve the problems contained in the worksheets on the material of the twovariable linear equation system.

c. Students can communicate mathematics into mathematical symbols.

d. Students can process and analyze data in worksheets.

e. Students can communicate the results of completing the test questions contained in student worksheets. 


\section{The stage of developing tools or instruments for student worksheets}

At this stage the researcher began to develop a student worksheet instrument on the material of two-variable linear equation systems. The student worksheet instrument design specifications are:

a. The instrument made was a student worksheet on the two-variable linear equation system material in the form of a lesson plan and an observation sheet using test techniques.

b. The material chosen to display the aspects of students' skills in problems in the material of two-variable linear equation systems because the two-variable linear equation system material requires high accuracy to solve the problems contained in student worksheet. Then in this material the skills of students in communicating mathematics are assessed as starting from planning, designing experiments, conducting experiments, communicating and making conclusions.

c. The product that has been developed will be validated by a team of experts or trainers. Validation was carried out by 1 mathematics education lecturer and 1 mathematics education teacher.

\section{Stage of developing learning strategies}

The result of this stage is that the researcher determines the learning strategy that will be applied in order to achieve the learning objectives that are expected to be achieved by students. The forms of learning strategies that can be used in implementing activities are learning activities, presentation of learning materials, and follow-up activities of learning activities. The learning strategy used is a problem-based learning model.

\section{The stage of developing teaching materials}

To support the learning strategies that have been designed, teaching materials in the form of student worksheets are also developed. Student worksheets that are made and validated by the validator in terms of format, content, and language through the consideration of experts or validators, it is hoped that student worksheets can be more easily used by students. Validation of student worksheets was carried out 3 times, namely on Tuesday, 17 September 2019 and Monday on 23 September 2019 and 24 September 2019. In the first stage of validation there are several suggestions as follows:
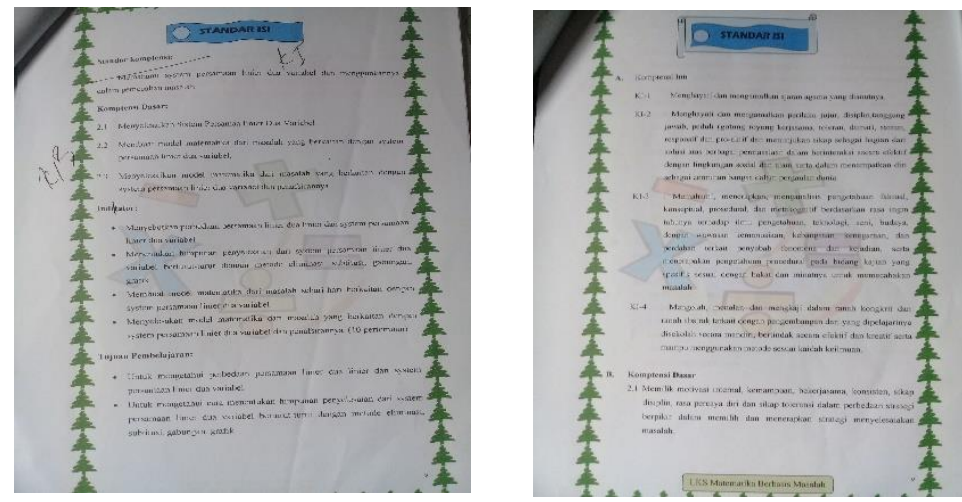

Figure 3. before and after revision 1 
The second validation was carried out on Monday 23 September 2019 validation was carried out after revision 1 . The validated product is called draft 2 . The validator's suggestions for student worksheet products are as follows:
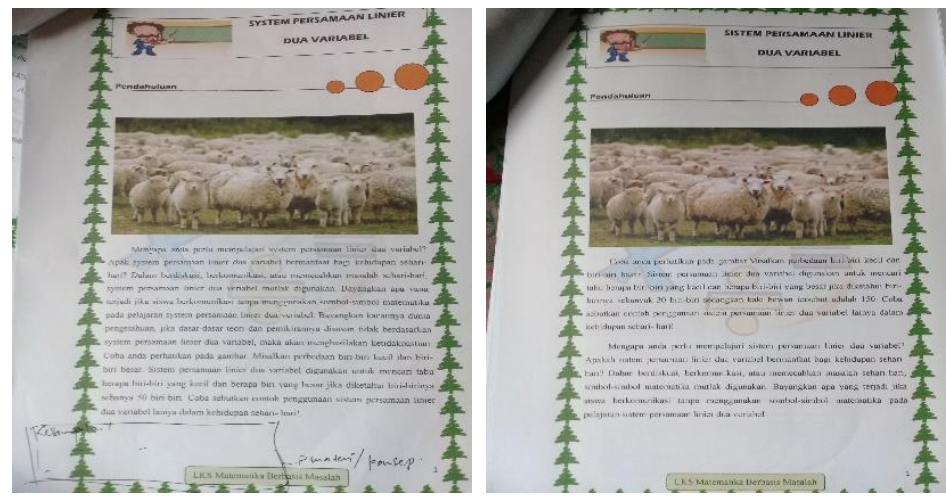

Figure 4. Before and after revision 2
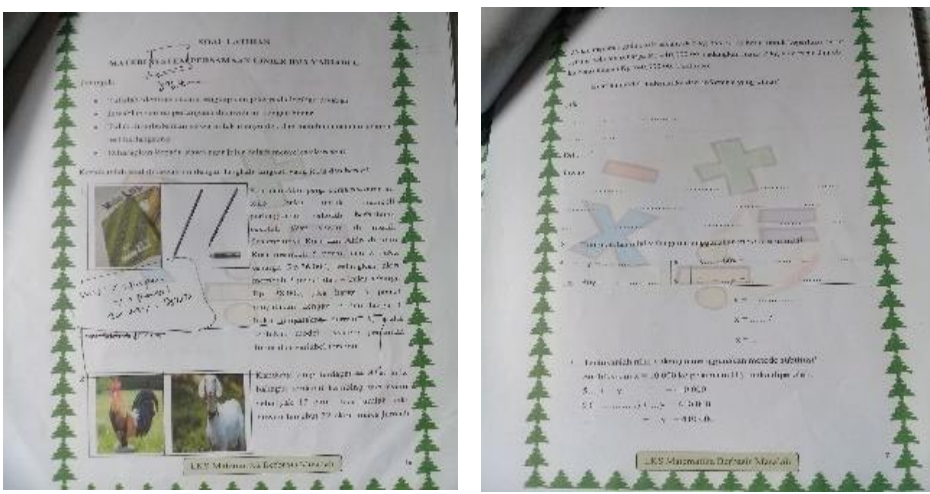

Figure 5. before and after revision 2

The third validation was carried out on 24 September 2019 validation was carried out after revision 2 . The validated product is called draft 3 . The validator's suggestions for student worksheet product are as follows:

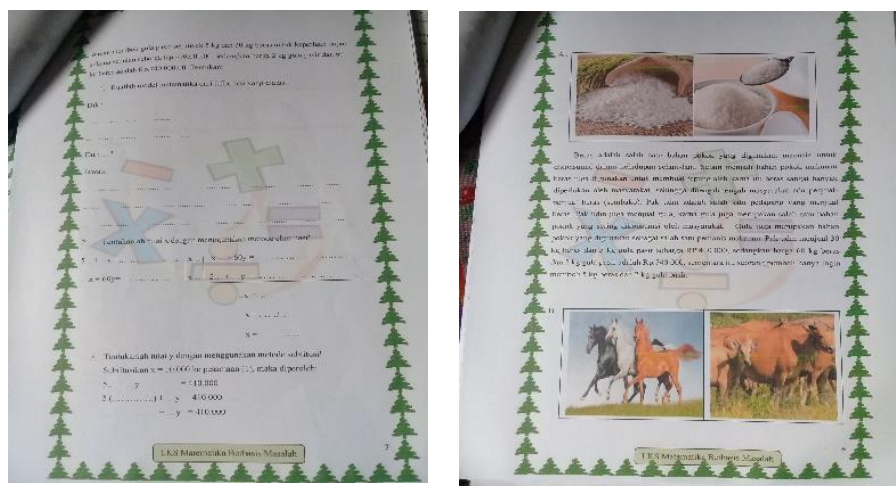

Figure 6. before and after revision 3 


\section{Design stage and formative evaluation}

The evaluation is done by asking the opinions of experts / validators about the product being developed based on the format, content and language, where the results of this evaluation can be used as input to improve the product being developed.

Table 5. validation results of student worksheets

\begin{tabular}{clcc}
\hline No & Rated aspect & Average score & Category \\
\hline 1 & Format & 3,8 & Valid \\
2 & Contents & 3,8 & Valid \\
3 & Language & 3,8 & Valid \\
4 & Material & 3,6 & Valid \\
\hline average number of scores & 3,75 & Valid \\
\hline
\end{tabular}

The results of the validation of the questions that were validated by the validator are as follows:

Table 6. description of the average results of the test question validation

\begin{tabular}{clc}
\hline No & Observed aspects & Scores \\
\hline 1 & Format & 4,0 \\
2 & Contents & 3,5 \\
3 & Language & 3,5 \\
\hline average number of scores & 3,7 \\
\hline
\end{tabular}

\section{Revision stage of student worksheets}

After the revision was complete, the student worksheet instrument was tried out in the first trial in class X MIA I Darul Aitami Private High School. The trial was carried out in small groups of 19 students and divided into 4 groups. While trial II was tried out in class $X$ MIA II was conducted in small groups of 21 students and divided into 4 groups. The student worksheet instrument is applied to its use in the learning process on the two-variable linear equation system material in class X MIA I in compulsory mathematics which is held by Ms. Nurhayati. The average score obtained by students when solving problems in student worksheets on the two-variable linear equation system material in the post-test results of the first trial of class X MIA I can be seen in the following table:

Table 7. description of post-test results of trial I of mathematical communication skills

\begin{tabular}{lc}
\hline \multicolumn{1}{c}{ Explanation } & $\begin{array}{c}\text { Post-test trial I of students' mathematical } \\
\text { communication skills }\end{array}$ \\
\hline Highest score & 90 \\
Lowest score & 52 \\
\hline
\end{tabular}


The average score obtained by students when solving problems in student worksheets on the two-variable linear equation system material on the post-test results of trial II in class X MIA II can be seen in the following table:

Table 8.

description of post-test results of trial II of mathematical communication skills

\begin{tabular}{lc}
\hline Explanation & $\begin{array}{c}\text { Post-Test Trial I of students' mathematical } \\
\text { communication skills }\end{array}$ \\
\hline Highest score & 94 \\
Lowest score & 63 \\
\hline
\end{tabular}

Based on tables 7 and 8 the descriptions of the post-test results of trial I and post-test of trial II were analyzed to determine the improvement in students' mathematical communication by comparing the average score of students obtained from the average results of post-test in trial I and post-test trial II, students' mathematical communication skills using problem-based learning can be described in the following table:

Table 9.

description of the average results of students' mathematical communication skills

\begin{tabular}{ccc}
\hline Explanation & $\begin{array}{c}\text { Post-test trial II of students' } \\
\text { mathematical } \\
\text { communication skills }\end{array}$ & $\begin{array}{c}\text { Post-test trial II of students' } \\
\text { mathematical } \\
\text { communication skills }\end{array}$ \\
\hline Highest score & 90 & 94 \\
Lowest score & 52 & 63 \\
Average & 73,4 & 80,3 \\
\hline
\end{tabular}

To make it easier for readers to get information quickly and easily to understand, the researcher also describes the average results of mathematical communication in the posttest trial I and post-test trial II in the following graphical form:

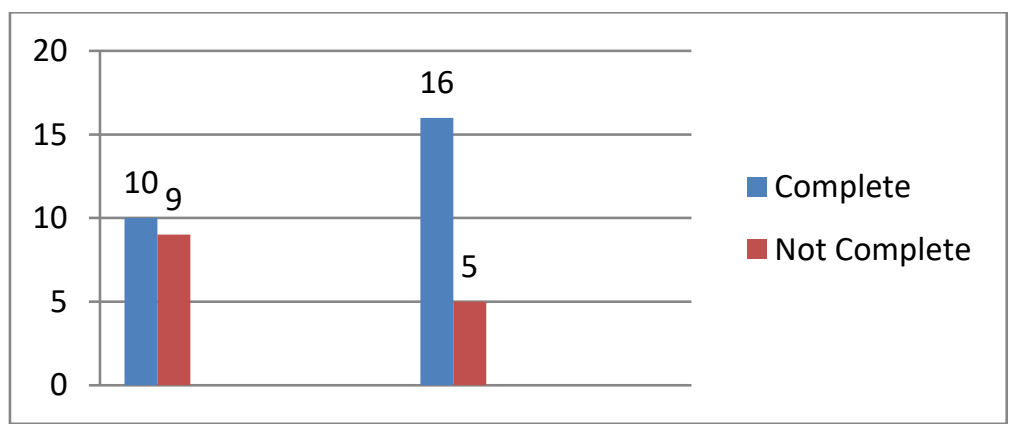

Figure 7. graph of the results of the post-test trial I and post-test trial II

Furthermore, the description of the increase in students 'mathematical communication skills by using student worksheets based on problem on the results of the post-test scores of trial I and post-test of trial II for each indicator of students' mathematical communication skills can be seen in table 10 as follows: 
Table 10. average mathematical communication skills of students for each indicator

\begin{tabular}{ccc}
\hline $\begin{array}{c}\text { Mathematical } \\
\text { communication skills } \\
\text { indicator }\end{array}$ & Post-test trial I & Post-test trial II \\
\hline Write & 2,75 & 3,5 \\
Draw & 1,75 & 2,22 \\
Mathematical expressions & 3,22 & 3,75 \\
\hline
\end{tabular}

\section{Design and developing a summative evaluation stage}

The final stage of Dick and Carrey model is a summative evaluation that is carried out after the program has been formatively evaluated and revised. This assessment is carried out by independent assessment. At this stage the researcher asks students to respond to the instrument that the researcher has developed, namely student worksheet in class X MIA II. This student response is done to see the extent of student interest in the student worksheet.

Based on the results of the analysis of average student response questionnaire, it can be seen from the percentage results of all aspects contained in student worksheet, namely students who are happy with student worksheet by $90.4 \%$ and only $6.7 \%$ who are less happy than the opinions of 21 students on student worksheet components.

\section{Conclusion}

Based on the results of the analysis and discussion in this study, the researcher can conclude several things, namely as follows:

1. The validity of the student worksheets developed in this study has an average total of 3.75 and is included in the valid category. Because the two validators give a good category, which means that the student worksheet developed by the researcher can be used with a little revision. Even so, further improvements and refinements or adjustments are still needed if the student worksheets are to be applied to other conditions.

2. The improvement of students 'mathematical communication skills using problem-based learning on the material of the two-variable linear equation system is the average achievement of students' mathematical communication skills in the post-test trial I of 73.4 and in the post-test of trial II of 80.3 and increased by 6.9.

3. Student responses to student worksheets that researchers have developed are judged by the goodness of student responses to student worksheets and it can be concluded that student responses to the components of student worksheets and learning activities using student worksheets get a positive response.

\section{References}

Aristia, K., Nasryah, C.E., \& Rahman, A.A. (2020). Efektifitas Penggunaan Media Pembelajaran Celengan Gambar Untuk Meningkatkan Hasil Belajar Siswa Tema Peduli Terhadap Makhluk Hidup Kelas IV SD. Edunesia: Jurnal Ilmiah Pendidikan, $1(2), 16-25$.

Ansari, B.I. (2012). Komunikasi Matematis Dan Politik Suatu Perbandingan Konsep Dan Aplikasi. Jakarta: Pena 
Betharia, P. (2016). Pengembangan Media Pembelajaran Teks Cerita Ulang Biografi Berbasis Adobe Flash Pro CS5 Pada Siswa SMA. Tesis: Universitas Negeri Medan.

Kurniawati, D., Masykuri, M., \& Saputro, S. (2016). Penerapan Model Pembelajaran Ingkuiri Terbimbing Dilengkapi LKS Untuk Meningkatkan Keterampilan Proses Sains Dan Prestasi Belajar. Jurnal Kimia, Vol 5, No 1: 88-95.

Kementerian Dan Kebudayaan. (2011). Survei Internasional TIMSS. [Online]. Tersedia: http/litbang. kemdikbud. go. id/index. php/survei-internasional-timss.

Kementerian Dan Kebudayaan. (2011). Survei Internasional PISA. [Online]. Tersedia: http/litbang.kemdikbud.go.id/index.php/survei-internasional-pisa.

Majid, A. (2017). Perencanaan Pembelajaran. Bandung: Remaja Rosdakarya.

Sudjana. N. (2005). Metode statistik. Bandung: Tarsito

Sulastri, S., Imran, I., \& Firmansyah, A. (2017). Meningkatkan Hasil Belajar Siswa Melalui Strategi Pembelajaran Berbasis Masalah Pada Mata Pelajaran IPS. Jurnal Kreatif Taduluko, Vol 3, No 1. 